\title{
Effect of Growth Retardants on Yield and Yield Contributing Characters in Mango (Mangifera indica L.) cv. Alphonso under Ultra High Density Plantation
}

\author{
B. Gopu ${ }^{1 *}$, T.N. Balamohan ${ }^{2}$, V.Swaminathan ${ }^{3}$, P. Jeyakumar ${ }^{4}$ and P. Soman ${ }^{5}$ \\ ${ }^{1}$ RVS Agricultural College, Thanjavur, Affiliated to Tamil Nadu Agricultural University, \\ Coimbatore, Tamil Nadu, India \\ ${ }^{2}$ Department of Vegetable Crops, Agricultural College and Research Institute, \\ Tamil Nadu Agricultural University, Madurai, Tamil Nadu, India \\ ${ }^{3}$ Horticultural College and Research Institute, Tamil Nadu Agricultural University, \\ Periyakulam, Tamil Nadu, India \\ ${ }^{4}$ Department of Crop Physiology, Agricultural College and Research Institute, \\ Tamil Nadu Agricultural University, Coimbatore, Tamil Nadu, India \\ ${ }^{5}$ Jain Irrigation Systems Ltd, Jalgaon, India \\ *Corresponding author
}

\section{A B S T R A C T}

\begin{tabular}{|l|}
\hline K e y w o r d s \\
Uniconazole, \\
Paclobutrazol, \\
Ethephon, Mango \\
flowering, \\
Fruit set and yield. \\
\hline Article Info \\
\hline $\begin{array}{l}\text { Accepted: } \\
\text { 28 September } 2017 \\
\text { Available Online: } \\
10 \text { November } 2017\end{array}$ \\
\hline
\end{tabular}

A field experiment was conducted to find out the effect of different growth retardants on yield and yield contributing characters in mango (Mangifera indica L.) cv. Alphonso under Ultra High Density Planting during 2013-2014 at Jain Irrigation Systems Limited (JISL) Farms, in Tamil Nadu. Eleven treatments with different combinations were imposed on five-year-old uniform sized Alphonso trees grown under a spacing of $3 \times 2 \mathrm{~m}$. The highest number of panicles per $\mathrm{m}^{2}$ canopy area and number of panicles per tree were recorded in the paclobutrazol treatments with application of ethephon or alone and in uniconazole (1.5 $\mathrm{g} / \mathrm{l})$ foliar spray. The treatments paclobutrazol $+\mathrm{KNO}_{3}$, uniconazole @ $1.5 \mathrm{~g} / \mathrm{l}$ and ethephon@ 500 ppm recorded the highest flowering intensity. However, paclobutrazol combined with ethephon or $\mathrm{KNO}_{3}$ and uniconazole alone recorded the advancement of flowering. The percentage of hermaphrodite flowers was higher in treatments where paclobutrazol combined with $1000 \mathrm{ppm}$ of ethephon and $\mathrm{KNO}_{3}$ spray. However, the paclobutrazol alone or with $\mathrm{KNO}_{3}$ and uniconazole alone recorded the highest percentage of fruit set in the trees. Higher concentration of uniconazole recorded the highest number

\section{Introduction}

Mango (Mangifera indica L.) is grown for the attractive colour, aroma and taste is commonly known as the 'King of fruits'. India continues to be the largest mango producing country of the world, accounting for more than 50 percent of the world production. Currently, mango is cultivated in an area of 2.5 million hectares with an annual production of 18 million tonnes in India. The productivity in India was only 7.2 tonnes $\mathrm{ha}^{-1}$ as against 45 tonnes $\mathrm{ha}^{-1}$ in Cape Verde Island. However, the productivity was lower 
in the countries producing mangoes commercially (Prakash and Singh, 2014). Improvement of productivity in mango continues to be the foremost issue for mango (Sauco, 1993). Of late, all the mango importing countries are considering India as a source of quality mangoes due to its varietal wealth and availability. Hence, it is imperative to improve the productivity and quality of Indian mangoes to meet the global need (Balamohan et al., 2014).

Reliable flowering is necessary to obtain consistent mango production in the tropics (Nagao and Nishina, 1993). Tropical climates are conducive to year-round vegetative growth of perennial tropical fruit crops, but flowering and fruit set are usually seasonal. Mango is a tropical evergreen fruit crop having a strong tendency towards alternate or biennial bearing habit (Reddy and Srilathav, 2014). Alternate bearing is one of the major problems in mango production all over the world including India (Silva et al., 2010 and 2013). Though several remedial measures have been suggested to overcome this problem none of these was successful until the advent of plant growth retardants (Gunjate, 2009). In commercial mango plantations, it is essential to control the vegetative growth and canopy size to get regular and uniform flowering. Paclobutrazol application with mild pruning was recorded the minimum number of days taken for first flowering and 50 per cent flowering under ultra high density planting in cv. Alphonso (Gopu, 2011).

Paclobutrazol is considered one of the best chemical growth regulators used for artificial induction of flowering in mango (Nartvaranant et al., 2000). The application of paclobutrazol followed by application of a dormancy-breaking substance $\left(\mathrm{KNO}_{3}\right)$ has forced mango, trees to produce flowers (Poerwantoet al., 2008). Paclobutrazol applied to the soil is used for the production management of mango in most of orchards, but it presents as disadvantage due to the greater persistence in plant and soil. However, it is necessary to identify other plant growth regulators that might be applied to the leaves, so as to minimize the risk of residues in the soil and plant (Mouco et al., 2013). Growth retardants had greater influence on the reproductive physiology of fruit trees (Grossman, 1992).

Uniconazole is applied as foliar spray to many crops as a gibberellin inhibitor. Results show that it is more effective than paclobutrazol and other triazoles (Warren et al., 1991). Tukey (1989) concluded that the effect of uniconazole applied as foliar spray is relatively quick when compared to paclobutrazol, allowing its use for the growth management of the aerial part. Silva et al., (2010) revealed that, uniconazole with two or three applications as a foliar spray shows an inhibition of vegetative development in mango variety 'Kent' and showed signs of flowering, even though they were at low proportions. Tandel and Patel (2011) reported that the application of ethrel was found effective for induction of early flowering compared to control. However, cultivar 'Alphonso' is distinctly erratic in bearing due to which its productivity is low compared to other popular cultivars (Panjavarnam, 2012). Hence, application of growth retardants was aimed to provide a more efficient crop management for this cultivar.

Therefore, floral induction is the basis for flowering and consequently fruiting in the tree where the growth retardants play an important role in such context. Keeping in view of the above mentioned facts, the present investigation was carried out to study the flowering and fruiting of mango cv. Alphonso after growth retardants manipulation under Ultra High Density 
Planting.

\section{Materials and Methods}

An investigation on "Effect of growth retardants on yield and yield contributing characters in mango (Mangifera indica L.) cv. Alphonso under Ultra High Density Planting" was undertaken at Jain Irrigation Systems Limited Farms, Udumalpet during 2013-2014. The experiment was laid out in a five-year-old trees with uniform sized trees spaced at $3 \times 2$ $\mathrm{m}$. The design was randomized block design having eleven treatments and three replication. Each treatmental unit consisted of ten trees replication ${ }^{-1}$. The crop was pruned mildly (tipping of past seasons shoots around 2-3 cm shoots were removed) after harvest and bordeaux paste was applied on the pruned twigs. The trees were maintained under uniform cultural practices during the investigation period. The treatments $\operatorname{areT}_{1}$ : Paclobutrazol (Soil application) - $1.0 \mathrm{~g}$ a.i $/ \mathrm{m}$ of canopy diameter, $\mathrm{T}_{2}: \mathrm{T}_{1}+\mathrm{KNO}_{3}-2 \%$ foliar spray, $\mathrm{T}_{3}$ : Uniconazole (foliar spray) $0.5 \mathrm{~g} /$ lit, $\mathrm{T}_{4}$ : Uniconazole (foliar spray) - 0.75 $\mathrm{g} /$ lit, $\mathrm{T}_{5}$ : Uniconazole (foliar spray) $-1.0 \mathrm{~g} / \mathrm{lit}$, $\mathrm{T}_{6}$ : Uniconazole (foliar spray) $-1.5 \mathrm{~g} / \mathrm{lit}, \mathrm{T}_{7}$ : Ethephon (foliar spray) - 500 ppm, $\mathrm{T}_{8}: \mathrm{T}_{1}+$ $\mathrm{T}_{7}, \mathrm{~T}_{9}$ : Ethephon (foliar spray) - $1000 \mathrm{ppm}$, $\mathrm{T}_{10}: \mathrm{T}_{1}+\mathrm{T}_{9}$ and $\mathrm{T}_{11}$ : control.

The growth retardant paclobutrazol (Cultar 23 $\%$ SC W/W of Syngenta Crop Science Ltd.) was drenched in the soil @ $1.0 \mathrm{~g} \mathrm{a.i} / \mathrm{m}$ of canopy diameter in the first week of September' 2013 by dissolving required quantity of chemical in 10 litres of water and this solution was poured in the root zone along the drip circle. For combined application of paclobutrazol and $\mathrm{KNO}_{3}$ spraying; $\mathrm{KNO}_{3}$ was sprayed 90 days after paclobutrazol application. The foliar spraying of uniconazole 95 per cent TC was purchased from Agro China Group, Shanghai, China. The growth retardant uniconazole was applied as foliar spray at twice, $1^{\text {st }}$ spray at turning green stage ( $1^{\text {st }}$ week of September' 2013) and $2^{\text {nd }}$ spray at one month after first spray. Spraying of Ethephon, the commercial formulation of ethrel (39\% ethephon) was used. Ethephon was sprayed at $1^{\text {st }}$ week of November '2013.For combined application of paclobutrazol and Ethephon; the ethephonspray was done 60 days after paclobutrazol application.

Data were recorded on length of panicle, number of panicles produced per $\mathrm{m}^{2}$ canopy area, number of panicle per tree, percentage of shoots with panicle, days taken for first flowering and 50 per cent flowering and percentage of hermaphrodite flowers was calculated by using the given formula:

Percentage of Hermaphrodite flowers $=$

Number of hermaphrodite flowers per panicle $x 100$

Total number of flowers per panicle

The percentage of fruit set was calculated at pea size stage as follows and expressed in percentage.

Number of fruits at pea size stage Percentage of fruit set = ---------------- x 100

Number of flowers per panicle

Number of fruits per tree and yield per tree were recorded. Data collected on flowering and yield characters were subjected to statistical scrutiny as per the methods suggested by Panse and Sukhatme (1985).

\section{Results and Discussion}

Flowering on current season shoots forced to go for pruning of temperate crops like apple, plum and peaches along with chemical for crop loading. Off late pruning is adopted in tropical trees also by advancing the pruning practices to allow shoots mature and produce 
flowering from the past season shoots. Under Ultra High Density Planting pruning is essential and unavoidable practices to maintain compact canopy for manageable limit. Pruning of shoots immediately after harvest is necessary to encourage early vegetative growth. The growing shoots will have to be checked by anti-gibberellins for flowering during the following season.

Given favourable growth conditions, the timing and intensity of flowering greatly determine productivity of mango in a given season (Davenport, 2011).Although the length of panicles is a varietal factor in mango, length of the panicle conduced to the very important one deciding yield and quality fruits. The present study showed that the treatment $\mathrm{T}_{9}$ registered the highest panicle length followed by $\mathrm{T}_{7}$ (Table 1). Spraying of ethephon resulted in getting highest length of panicle. However, paclobutrazol application combined with $\mathrm{KNO}_{3}$ or ethephon with higher concentration (1000 ppm) had not influenced the length of panicle. It was suggested that the retardants will never allow any luxury growth. Similar reduction in panicle length in paclobutrazol treated trees was reported by Hoda et al., (2001) and Shinde et al., (2000).

In an evergreen tree like mango which exhibit alternate bearing tendency, crop regulation is essential for which encourage sufficient number of panicles per $\mathrm{m}^{2}$ canopy area and number of panicle per tree are required. Productivity is dependent of those two factors.

Flowering in mango is associated with reduced vegetative growth often induced by lower activity of gibberellins (Voon et al., 1991). The number of panicles produced per $\mathrm{m}^{2}$ canopy area and number of panicle per tree were significantly influenced by the growth retardant treatments (Table 1). The treatment $\mathrm{T}_{8}$ and was on par with $\mathrm{T}_{6}$ recorded the highest number of panicles per $\mathrm{m}^{2}$ canopy area, while, lowest in $\mathrm{T}_{11}$ (control). Hence, the treatment $\mathrm{T}_{6}$ recordedthe highest number of panicle per tree, while lowest in $T_{11}$ (control).The study revealed that the application of paclobutrazol and uniconazole which are of triazole compounds induced flower bud formation by lowering gibberellins content in the shoot tip.

Triazoles compounds are anti-giberellic could alter the levels of gibberellins in shoot buds. Burondkar and Gunjate (1993) also indicated that paclobutrazol application increased the number of flowering shoots due to lower vegetative growth and higher reserves in the tree. Similar results were also obtained by Silva et al., (2010) in mango cv. Kent. Alphonso is a variety often enters in to alternate bearing habit it can be possible with break that alternate bearing with growth retardants. The triazole products help to shift the vegetative phase into flowering in 'Tommy Atkins' a cultivar difficult to change the phase (Davenport, 2007).

The highest percentage of shoots with panicle was recorded in the treatment $\mathrm{T}_{10}$ and was on par with $\mathrm{T}_{8}$. However, the least was recorded by $\mathrm{T}_{11}$ in Alphonso (Table 1). It is obvious that when compared to control, paclobutrazol along with ethephon had higher percentage of shoots with panicle.

Ethrel releases ethylene which comes in contact with the plant tissue, triggers the mechanism of flowering and brings the shoots to flowering (Tandel and Patel, 2011) in matured shoots. Similar results were obtained by Mendonca (2003) in mango when paclobutrazol and ethephon were combined.

Evergreen, unlike deciduous trees, do not normally store large reserves of manufactured foods and the growth is more closely related to currently available status of nutrients. Producing early mango fruit may enhance the economic returns by avoiding the period of 
peak harvest.

Table.1 Effect of growth retardants on length of panicle, number of panicles produced per $\mathrm{m}^{2}$ canopy area, number of panicle per tree and percentage of shoots with panicle in mango cv. Alphonso

\begin{tabular}{|c|c|c|c|c|}
\hline Treatments & $\begin{array}{c}\text { Length of } \\
\text { panicle }\end{array}$ & $\begin{array}{c}\text { No. of panicles produced } \\
\text { per } \mathbf{~ m}^{\mathbf{2}} \text { canopy area }\end{array}$ & $\begin{array}{c}\text { No. of panicle } \\
\text { per tree }\end{array}$ & $\begin{array}{c}\text { Percentage of shoots } \\
\text { with panicle }\end{array}$ \\
\hline $\mathbf{T}_{\mathbf{1}}$ & 27.83 & 25.42 & 157.44 & 53.46 \\
\hline $\mathbf{T}_{\mathbf{2}}$ & 25.43 & 29.44 & 174.33 & 57.94 \\
\hline $\mathbf{T}_{\mathbf{3}}$ & 27.65 & 16.15 & 100.44 & 35.30 \\
\hline $\mathbf{T}_{\mathbf{4}}$ & 27.80 & 24.06 & 154.11 & 46.79 \\
\hline $\mathbf{T}_{\mathbf{5}}$ & 28.74 & 24.42 & 155.72 & 50.01 \\
\hline $\mathbf{T}_{\mathbf{6}}$ & 26.72 & 31.97 & 199.00 & 57.33 \\
\hline $\mathbf{T}_{\mathbf{7}}$ & 30.99 & 10.33 & 61.56 & 19.15 \\
\hline $\mathbf{T}_{\mathbf{8}}$ & 26.21 & 32.42 & 184.11 & 60.92 \\
\hline $\mathbf{T}_{\mathbf{9}}$ & 31.90 & 11.17 & 70.33 & 22.20 \\
\hline $\mathbf{T}_{\mathbf{1 0}}$ & 24.78 & 30.00 & 160.11 & 62.73 \\
\hline $\mathbf{T}_{\mathbf{1 1}}$ & 30.69 & 4.36 & 16.00 & 4.89 \\
\hline $\mathbf{S E d}$ & $\mathbf{0 . 6 8 2}$ & $\mathbf{0 . 3 5 7}$ & $\mathbf{1 . 9 2}$ & $\mathbf{1 . 1 6}$ \\
\hline $\mathbf{C D}(\mathbf{0 . 0 5})$ & $\mathbf{1 . 4 2 4}$ & $\mathbf{0 . 7 4 4}$ & $\mathbf{4 . 0 1}$ & $\mathbf{2 . 4 2}$ \\
\hline
\end{tabular}

Table.2 Effect of growth retardants on days to taken for first flowering, days to taken for $50 \%$ flowering, percentage of hermaphrodite flowers/panicle, percentage of fruit set, number of fruits per tree and yield per tree $(\mathrm{kg})$ in mango cv. Alphonso

\begin{tabular}{|c|c|c|c|c|c|c|}
\hline Treatments & $\begin{array}{l}\text { Days to taken } \\
\text { for first } \\
\text { flowering }\end{array}$ & $\begin{array}{l}\text { Days to taken } \\
\text { for } 50 \% \\
\text { flowering }\end{array}$ & $\begin{array}{c}\text { Percentage of } \\
\text { hermaphrodite } \\
\text { flowers/panicle }\end{array}$ & $\begin{array}{c}\text { Percentage } \\
\text { of } \\
\text { fruit set }\end{array}$ & $\begin{array}{c}\text { Number of } \\
\text { fruits per } \\
\text { tree }\end{array}$ & $\begin{array}{l}\text { Yield } \\
\text { per tree } \\
(\mathrm{kg})\end{array}$ \\
\hline $\mathbf{T}_{1}$ & 154.53 & 185.70 & 15.11 & 0.659 & 55.10 & 12.10 \\
\hline $\mathbf{T}_{2}$ & 153.67 & 181.00 & 18.72 & 0.692 & 57.16 & 12.29 \\
\hline $\mathbf{T}_{3}$ & 180.85 & 201.85 & 14.02 & 0.654 & 37.00 & 8.47 \\
\hline$T_{4}$ & 172.58 & 193.25 & 14.39 & 0.659 & 40.89 & 9.13 \\
\hline$T_{5}$ & 171.84 & 191.51 & 16.56 & 0.740 & 51.83 & 10.38 \\
\hline$T_{6}$ & 160.47 & 180.30 & 17.02 & 0.759 & 56.00 & 13.67 \\
\hline $\mathbf{T}_{7}$ & 186.07 & 204.17 & 12.92 & 0.574 & 18.00 & 3.74 \\
\hline $\mathbf{T}_{8}$ & 161.80 & 187.30 & 18.64 & 0.729 & 46.94 & 9.40 \\
\hline $\mathbf{T}_{9}$ & 190.00 & 207.17 & 12.84 & 0.586 & 22.11 & 4.43 \\
\hline$T_{10}$ & 159.93 & 185.43 & 17.54 & 0.718 & 53.00 & 10.42 \\
\hline$T_{11}$ & 223.35 & 229.85 & 10.37 & 0.439 & 10.33 & 1.93 \\
\hline SEd & 3.60 & 4.33 & 0.384 & 0.011 & 0.964 & 0.206 \\
\hline CD (0.05) & 7.50 & 9.03 & 0.802 & 0.023 & 2.011 & 0.430 \\
\hline
\end{tabular}

Though very early panicle emergence in mango is desirable in south India, in the present investigation without growth retardantsthe flowering was delayed considerably (Table 2). The treatments $\mathrm{T}_{2}$ recorded the early flowering. However, early 
50 per cent flowering was recorded by $\mathrm{T}_{6}$. Growth retardants paclobutrazol where combined with $\mathrm{KNO}_{3}$ and uniconazole alone had the shoots with desired maturity gave rise to early flowering and 50 per cent flowering compared to control. Early flowering in paclobutrazol treated trees was also reported by Kulkarni (1988), Gopu, (2011) and Panjavarnam (2012). Application of paclobutrazol and uniconazole encouraged early reduction of endogenous the gibberellins levels within the shoots which in turn resulted in earlier maturity than untreated control (Protacio et al., 2013; Sarker and Rahim, 2012; Burondkar and Gunjate, 1991).

The hormonal concept of flowering in mango implied that the cyclic synthesis of floral stimulus in the leaves and the difference between two such cycles would determine the flowering behaviour of a cultivar (Kulkarni, 1988). In general, triazoles, owing to its anti gibberellin activity, could induce or intensify flowering by blocking the conversion of kaurene to kaurenoic acid (Voon et al., 1991).

Percentage of hermaphrodite flowers per panicle has direct relationship with fruit set and fruit yield. The development of hermaphrodite flowers needed more reserves from the tree than unisexual flowers because of the additional structures required. In the current observation, the treatment $T_{2}$ recorded the highest percentage of hermaphrodite flowers per panicleand was on par with $T_{8}$ and the least was recorded in $\mathrm{T}_{11}$ (Table 2).

Otherwise the percentage of hermaphrodite flowers was higher in the treatment where paclobutrazol combined with ethephonor $\mathrm{KNO}_{3}$ spray. A higher percentage of hermaphrodite than male flowers following paclobutrazol treatment was also observed in Alphonso mango as reported by Vijayalakshmi and Srinivasan, (2002); Dharmar (2011) and with $\mathrm{KNO}_{3}$ spray by
Rebolledo et al., (2008) and Panjavarnam, (2012) in mango.

Mango a profuse flowering tree, has the problem of low fruit set capacity. Hence, knowledge on the fruit setting ability is highly essential under crop regulation practices. In the present investigation, the treatment $\mathrm{T}_{6}$ (uniconazole $1.5 \mathrm{~g} / \mathrm{lit}$ ) recorded the highest percentage of fruit set and was on par with $\mathrm{T}_{5}$ (uniconazole $1.0 \mathrm{~g} / \mathrm{lit}$ ). However, the treatment $\mathrm{T}_{11}$ recorded the lowest percentage of fruit set (Table 2). This is in conformity with the findings of Basak and Niezborala (1991) in apple with uniconazole application. The reasons attribute where reduced shoot length, which leads to more light interception and movement of assimilate partitioning caused rapid development of reproductive buds by interfering with gibberellin metabolism. In mango, the flowers emerge mostly at terminals i.e., very near to sink and there is every possibility of increase drawal of more nutrients from the source towards the sink (Gopu et al., 2014). The effect of quick shifting of assimilates chlorophyll, mineral elements, soluble proteins in leaves, stems and root to the sink (Wang et al., 1995) are considered vital for better fruit set and development.

In the present investigation, the treatment paclobutrazol $+\mathrm{KNO}_{3}\left(\mathrm{~T}_{2}\right)$ recorded the highest number of fruits and was on par with uniconazole@1.5 g/l $\left(\mathrm{T}_{6}\right)$ which also was recorded higher yield and the least number of fruits per tree and yield were recorded in control $\left(\mathrm{T}_{11}\right)$ (Table 2). Maximum number of fruits per tree and yield recorded by paclobutrazol and uniconazole treated trees, might be due to the consequences of changes induced by growth retardant on overall physiology of mango trees viz., improved nutrient uptake, rapid and enhanced photosynthate re-allocation and altered hormonal balance. Similar findings were obtained by Upreti et al., (2013) and Anez (2009) in mango. Application of uniconazole 
(two sprays) with higher concentration of 1$1.5 \mathrm{~g} / 1$ was observed to increase the fruit yield in mango cv. Alphonso. Similar findings were reported by Broadley et al., (2005) in custard apple.

Based on the results of this study, it can be concluded that two foliar applications of uniconazole@ $1.5 \mathrm{~g} / \mathrm{l}\left(\mathrm{T}_{6}\right)$ had a positive effective on for increasing the yield and yield contributing characters in mango cv. Alphonso under Ultra High Density planting.

\section{Acknowledgement}

We thank M/s. Jain Irrigation Systems Limited, Udumalpet unit for providing research fellowship and necessary facilities to conduct the experiment using Ultra High Density Planting in mango.

\section{References}

Anez, M. 2009. Paclobutrazol and ammonium and potassium thiosulphates in mango 'Haden' production.Acta Hort., 820: 419-423.

Balamohan T.N, R. Arulmozhiyan, A. Nithiya Deviand Maheshwari, N. 2014.Value chain management in mango. In: National conference on value chain management in mango held at Kolar, Karnataka, pp. 24-28.

Basak, A and Niezborala, B. 1991.The influence of Sumi 7 (S-3307D) on vegetative growth and bearing of apple trees.Acta Hort., 239: 309-310.

Broadley, R. H., A.P. George and Nissen, R. J. 2005. Innovative production systems for the Australian custard apple industry. Acta Hort., 694: 277-282.

Burondkar M. $\mathrm{M}$ and Gunjate, R. T. 1991.Regulation of shoot growth and flowering habit in Alphonso mango with paclobutrazol. Acta Hort., 291: 7984.
Burondkar, M. $\mathrm{M}$ and Gunjate, R.T. 1993.Control of vegetative growth and inductive of regular and early cropping in 'Alphonso' mango with paclobutrazol. Acta Hort., 341: 206-215.

Davenport, T. L. 2007. Reproductive physiology of mango. Braz. J. Plant Physiol., 19(4):363-376.

Davenport, T. L. 2011. Mango reproductive physiology, challenges and opportunities. Global conference on augmenting production and utilization of mango: biotic and abiotic stress. pp. 58-71.

Dharmar, T. 2011. Studies on chemical manipulation for inducing flowering and fruiting in mango (Mangifera indica L.) cv. Alphonso. M.Sc., (Hort.) thesis submitted to HC \& RI, TNAU, Periyakulam.

Gopu, B. 2011.Canopy management studies in mango (Mangifera indica L.) cv. Alphonso under ultra high density planting. M.Sc (Hort.) thesis submitted to the HC \& RI, Tamilnadu Agricultural university, Coimbatore.

Gopu, B., T. N. Balamohan, P. Soman and Jeyakumar, P. 2014. Canopy management in mango (Mangifera indica L.) cv. Alphonso with reference to flowering, yield and quality characters under Ultra High Density Planting.J. Appl. Hort., 16 (1): 50-53.

Grossman, K. 1992. Plant growth retardants: Their mode of action and beneficial for physiological research.In: Progress in Plant Growth Regulation. C. Karssen; L. Van Loon and D. Vreugdenhil (Eds.). Kluwer Academic Publishers Netherlands. pp. 788-797.

Gunjate, R. T. 2009. Advances in mango culture in mango. Acta Hort., 820: 6978.

Hoda, M. M., S. Singh and Singh, J. 2001. Effect of cultar on flowering, fruiting and fruit quality of mango 
cv.Langra.Indian. J. Hort., 58(3): 224 227.

Kulkarni, V. J. 1988. Chemical control of tree vigour and promotion of flowering in mango (Mangifera indica L.) using paclobutrazol. J. Hort. Sci., 63(3): 557566.

Mendonca, V, J. D. Ramos,J. B. Menezes, R. Inneccoand Pio, R. 2003.Utilization of paclobutrazol, ethephon and potassium nitrate in the flowering induction of mango in the semi-arid northeast. Ciencia-e-Agrotechnologia, 27 (6): 12851292.

Mouco, M.A.D.C., E. O. Ono, J. D. Rodriguesand Silva, G. J. N. 2013.Plant regulators on vegetative growth of 'Tommy Atkins' mangoes. Acta Hort., 992: 187-192.

Nagao, M. A and Nishina, M. S. 1993.Use of potassium nitrate on mango flowering. Proceedings: Conference on mango in Hawaii. College of tropical agriculture and human resources. University of Hawaii, pp. 61-66.

Nartvaranant, P., S. Subhadrabandhu and Tongumpai, P. 2000. Practical aspect in producing off season mango in Thailand. Acta Hort., 509(2): 661-668.

Panjavarnam, G. 2012.Studies on the effect of different chemicals and paclobutrazol on flowering and fruiting in mango (Mangifera indica L.) cV. Himampasand. M.Sc., (Hort.) thesis submitted to $\mathrm{HC} \& \mathrm{RI}$, TNAU, Periyakulam.

Panse, V. G and Sukhatme, P. V. 1985.Statistical Methods for Agricultural Workers. ICAR, New Delhi.

Poerwanto, R, D. Efendi, W. D. Widodo, S. Susanto and Purwoko, B. S. 2008.Offseason production of tropical fruits.Acta Hort., 772: 127-133.

Prakash, J and Singh, A. K. 2014.Challenges for improving productivity and achieve profitability in mango: Issue and strategies. In: Knowledge sharing workshop on tropical fruits held at Coimbatore, Tamil Nadu, pp. 96-99.

Protacio, C. M. 2013.Towards a good agricultural practices (GAP) - compliant mango production system in the Philippinnes. Acta Hort., 992: 69-73.

Ram, S and Tripathi, P. C. 1993.Effect of cultar on flowering and fruiting in high density Dashehari mango trees. Indian J. Hort., 50: 292-295.

Rebolledo, M. A., D. A. Pal and Jose, R. M. 2008.Effects of paclobutrazol and $\mathrm{KNO}_{3}$ over flowering and fruit quality in two cultivars of mango manila. Communcacious reports communicacoes. 33: 518-522.

Reddy, Y. T. N and Srilathav.2014. High density planting and canopy management in mango.. In: National conference on value chain management in mango held at Kolar, Karnataka.

Sarker, B. C and Rahim, M. A. 2012.Vegetative growth, harvesting time, yield and quality of mango (Mangifera indica L.) as influenced by soil drench application of paclobutrazol. Bangladesh J. Agril. Res. 37(2): 335348.

Sauco, G. V. 1993. The situation of mango culture in the word.Acta Hort., 341: 3138.

Shinde, A. K., B. H. Waghmare, R. G. Waghandand Burondkar, H.M. 2000. Effect of dose and time of paclobutrazol application on flowering and yield of mango. Indian J. Plant. Physiol., 5(1): 82-84.

Silva, G. J. N., E. M. Souza, J. D. Rodrigues, E. O. Ono and Mouco, M. A. C. 2010. Uniconazole on mango floral induction cultivar 'Kent' at submediosaofrancisco region, Brazil. Acta Hort., 884: 677682.

Silva, G. J. N., E. M. Souza, J. D. Rodrigues, 
E. O. Onoand Mouco, M. A. C. 2013. Floral induction of mango 'Tommy Atkins' at submediosaofrancisco, region, Brazil. Acta Hort., 992: 149154.

Tandel, Y. N and Patel, N. L. 2011.Effect of chemicals on growth, yield and economics of mango (Mangifera indica L.).Karnataka J. Agric. Sci., 24 (3): $362-365$.

Tukey, L. D. 1989. Uniconazole - A new triazole growth regulant for apple. Acta Hort., 239: 249-252.

Upreti, K. K., Y. T. N. Reddy, S. R. S. Prasad, G. V. Bindu, H. L. Jayaram and Rajan, S. 2013. Hormonal changes in response to paclobutrazol induced early flowering in mango cv. Totapuri. Sci. Hort., 150: 414-418.
Vijayalakshmi, D and Srinivasan, P. S. 2002.Impact of chemicals and growth regulators in induction of flowering in 'off' year mango cv. Alphonso. Orissa J. Hort., 30(2): 25-32.

Voon, C. H, C. Pitakpaivan and Tan, S. J. 1991.Mango cropping manipulation with Cultar. Acta Hort., 291: 219-228.

Wang,S. Y., T. Sun, Z. L. JiandFaust, M. 1995.Effect of paclobutrazol on water stress induced ethylene bio-synthesis and polyamine accumulation in apple seedlings leaves. Phytochem., 24: 21852190.

Warren, S. L., F. A. Blazichand Thetfort, M. 1991. Whole-plant response of selected woody landscape species to uniconazole. J. Environ. Hort., 9: 163167.

\section{How to cite this article:}

Gopu, B., T.N. Balamohan, V. Swaminathan, P. Jeyakumar and Soman, P. 2017. Effect of Growth Retardants on Yield and Yield Contributing Characters in Mango (Mangifera indica L.) cv. Alphonso under Ultra High Density Plantation. Int.J.Curr.Microbiol.App.Sci. 6(11): 3865-3873. doi: https://doi.org/10.20546/ijcmas.2017.611.453 